\title{
Even Lower is Possible: Impact of Flow Rate on Safety Issues in Low Flow Anaesthesia
}

\section{Daha Azı Da Mümkün: Düșük Akımlı Anestezide Akım Hızlarının Güvenlik Sonlanımları Üzerine Etkisi}

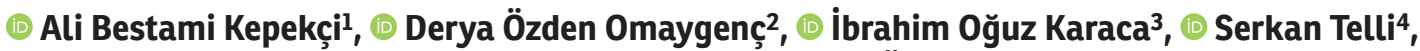 \\ (1) Serkan Yücepur ${ }^{5}$, (1) Ecder Özenç

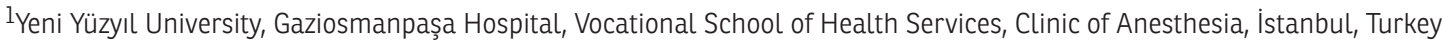 \\ ${ }^{2}$ Yedikule Chest Diseases and Chest Surgery Training and Research Hospital, Clinic of Anesthesiology, İstanbul, Turkey \\ ${ }^{3}$ Istanbul Medipol University Hospital, Clinic of Cardiology, İstanbul, Turkey \\ ${ }^{4}$ Atatürk University Research Hospital, Clinic of Anesthesiology and Reanimation, İstanbul, Turkey \\ 5 Amasya Suluova State Hospital, Clinic of Anesthesiology and Reanimation, İstanbul, Turkey \\ 6University of Health Sciences, Haseki Training and Research Hospital, Clinic of Anesthesiology and Reanimation, İstanbul, Turkey
}

\section{ABSTRACT}

Objective: Although various issues about low flow anaesthesia had been investigated previously, impact of different flow rates on perioperative follow-up and safety outcomes were not well-addressed. Here, we aimed to assess the influence of different flow rates of low flow fresh gas mixtures on hemodynamic state, gas exchange parameters and recovery time during general anaesthesia of urogenital system operations in a single tertiary centre.

Materials and Methods: Sixty-two patients (American Society of Anaesthesiologists score I or II) to whom low flow anaesthesia with sevoflurane had been administered were subsequently gathered in three distinct $-\mathrm{A}$, moderate flow $(2 \mathrm{~L} /$ minimum), $\mathrm{B}$, low flow $(1 \mathrm{~L} /$ minimum), $\mathrm{C}$, minimal flow $(0.5 \mathrm{~L} /$ minimum) -groups. Hemodynamic data before and during anaesthesia, additionally, gas exchange and blood gas analysis parameters at $30^{\text {th }}$ minute and before cessation of anaesthesia were recorded. Recovery period was observed by a second physician and times of interest were noted.

Results: Demographic characteristics were similar among study groups. Most of the data regarding vital signs, gas exchange and blood gas analysis at the $30^{\text {th }}$ minute and prior to cessation of anaesthesia were comparable. During operation, inspiratory sevoflurane levels were significantly higher in group A $(1.7 \pm 0.6$ vs $1.3 \pm 0.3$ vs $1.3 \pm 0.3, p=0.043)$. There were no significant differences between the groups in terms of recovery data [time to spontaneous breathing $(p=0.21)$, time to extubation ( $p=0.113)$, time to eye opening ( $p=0.5)$, time to verbal response $(\mathrm{p}=0.518$ ) and time to reach a Modified Aldrete score of 9 or 10 (minimum, $13.7 \pm 6.8$ vs $13.6 \pm 5.2$ vs $14.8 \pm 4, p=0.717)$ ).

Conclusion: Limiting the flow rate of gas mixture to $0.5 \mathrm{~L} /$ minutes in low flow anaesthesia maintenance may facilitate reduced utilization of volatile anaesthetics without a compromise in hemodynamic status and recovery process.

Keywords: Anesthesia, inhalation, recovery period, sevoflurane

ÖZ

Amaç: Düșük akımlı anesteziyle ilișkili birçok araștırma yapıımıș olsa da, operasyon sırasında takip verileri ve güvenlik sonlanımları üzerine farklı akım hızlarının etkileri net olarak bilinmemektedir. Üçüncü basamak bir merkezde ürogenital sistem operasyonları sırasında uygulanan genel anestezi için düşük akımlı taze gaz karışımlarının farklı akım hızlarında kullanıldığı bu çalışmada, hemodinami, gaz değişim verileri ve derlenme zamanlarının gruplar arasında farkııık arz edip etmediği araşsııılmışıı.

Gereç ve Yöntemler: Sevofluran ile düșük akımlı anestezi uygulanan ardıșık altmıș iki hasta (Amerikan Anestezistler Derneği skoru I veya II) üç grupta toplandı: A, orta akım (2 L/dk), B, düşük akım (1 L/dk), C, minimal akım (0,5 L/dk). Operasyon öncesinde ve sırasında kaydedilen hemodinamik verilere ek olarak, 30. dakika ve anestezi sonlandırılmadan hemen önceki gaz değişim ve arter kan gazı değerleri incelendi. Derlenme ikinci bir hekim tarafından gözlendi ve gerekli süreler not edildi.

Bulgular: Çalıșma grupları arasında demografik özellikler benzerdi. Otuzuncu dakika ve anestezi sonlanımı öncesi vital bulgular, gaz değişim ve arter kan gazı analizi

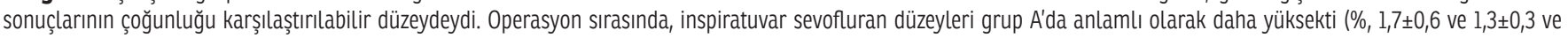
$1,3 \pm 0,3, p=0,043)$. Derlenme zamanları açııından gruplar arasında fark tespit edilmedi [spontan soluma zamanı ( $p=0,21)$, ekstübasyon zamanı ( $(\mathrm{z}=0,113)$, göz açma zamanı ( $p=0,5)$,

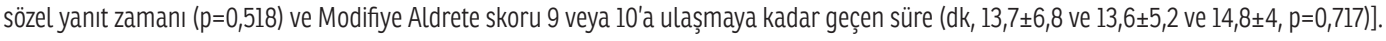

Sonuç: Düşük akımlı anestezi idamesinde gaz karıșımının akım hızını 0,5 L/dk'ya kadar düşürmek, hemodinamik istikrar ve derlenme sürecine ilișkin herhangi bir taviz vermeden volatil anestetik ajanların tüketiminin azaltılmasına yardımcı olabilir.

Anahtar kelimeler: Anestezi, inhalasyon, derlenme dönemi, sevofluran

Received/Geliș tarihi: 5.10.2017 | Accepted/Kabul tarihi: 29.12.2017

Address for Correspondence/Yazıșma Adresi: Derya Özden Omaygenç, Yedikule Chest Diseases and Chest Surgery Training and Research Hospital, Clinic of Anesthesiology, İstanbul, Turkey

Phone/Telefon: +90 5054424719 E-mail/E-posta: drderyaozden@yahoo.com ORCID-ID: orcid.org/0000-0003-1037-8915

Citation/Atıf: Kepekçi AB, Omaygenç DÖ, Karaca IO, Telli S, Yücepur S, Özenç E. Even Lower is Possıble: Impact of Flow Rate on Safety Issues in Low Flow Anaesthesıa. Bakırköy Tıp Dergisi 2019;15:15-23. https://doi.org/10.4274/ BTDMJB.galenos.2017. 20171005064643 


\section{INTRODUCTION}

Low flow anesthesia, recently and repetitively drew interest in clinical practice thanks to constantly innovating anaesthetic techniques and monitoring devices. The method relies upon reinhalation at least $50 \%$ of a fresh gas mixture comprising volatile anaesthetics and oxygen sufficient, for providing metabolic demands which is obtained from expirated gases after removal of $\mathrm{CO}_{2}(1,2)$. Reduced costs, prevention of air pollution, and preserved body heat and moisture might be considered as main advantages of low flow anaesthesia $(3,4)$. Moreover, anesthesia with low fresh gas flow improves the flow dynamics of the inhaled air and increase mucociliary clearance $(5,6)$. From the financial point of view, routine administration of low flow anaesthesia can result in up to $75 \%$ reduction of expenditures (7). Along with the benefit of minimizing the emission of nitrous oxide -one of the major human derived ozone-depleting and heat-trapping gases-, global gas exposure of operation room personnel is decreased as well (4). Finally, risk of hypoventilation due to potential leaks, extensive system volume, the discrepancy between the delivered fraction and the inspired fraction of inhaled gases and the risk of accumulation of toxic compounds can be counted as main hazards (8).

Although these abovementioned issues about low flow anaesthesia had been investigated previously in general terms, safety of extremely low flow rates (namely $0.5 \mathrm{~L}$ / minutes for maintenance in our study) as compared to conventional rates were not specifically addressed. Regarding the rationale of establishing the lowest possible flow rate that may not jeopardize patients' well-being, we analysed the data (including hemodynamic state, gas exchange parameters and recovery time) of a sample population who underwent various urogenital system operations under inhalation anesthesia with different flow rates in a single tertiary centre.

\section{MATERIALS AND METHODS}

American Society of Anesthesiologists (ASA) score of I or II patients scheduled for elective urogenital operations under general anesthesia were enrolled for evaluation. Patient inclusion and randomization were carried out between February 2013 and October 2013 in a single tertiary health center and the study was approved by local Ethics Committee. Oral and written informed consent was obtained from all participants. 152 patients were evaluated for eligibility to be involved in study population and 90 of them were excluded mainly because of not meeting the criteria about age limits and procedure times. Eventually 62 patients were found to be suitable and assembled in three distinct groups. The age of sample population ranged between 18-70 years old. In general anaesthesia volatile anaesthetic agents -sevoflurane and nitrous oxide- were invariably utilized. Individuals with ischemic heart disease and severely reduced contractile function -left ventricular ejection fraction $<35 \%$-, significant anemia, chronic obstructive lung disease, uncontrolled diabetes mellitus and arterial hypertension, morbid obesity, hepatic or renal failure were excluded. Besides extremes of age, drug or alcohol abusers, pregnant or lactating women, patients with a history of malignant hyperthermia and those with excessive procedure times $->4$ hours- were postulated as unsuitable for investigation and had not been involved.

Patients were assigned to three groups according to flow rates by simple randomization with random digits. Sample size was determined in accordance with available resources and mid-term analysis results.

\section{Features of the Operation Room and Anaesthetic Technique}

The whole study population was premedicated with $1 \mathrm{mg}$ midazolam thirty minutes before entering the room. A specific attention was paid to keep the room at a constant temperature of $21-22^{\circ} \mathrm{C}$ during the entire procedure. Before induction, rhythm with $\mathrm{D} 2$ derivation on electrocardiogram, non-invasive blood pressure and pulse oxymeter monitorizations were performed. MS13466E539D (Infinity ${ }^{\circledR}$ Delta, Dräger Medical Inc. Telford, USA) was used for continuous monitoring of hemodynamic and gas exchange parameters.

Potential leakages from anaesthesia circuits were checked and gas exchange monitors were calibrated before each procedure. The circuits and anti-bacterial filters were disposable. Inspiratory carbon dioxide $\left(\mathrm{CO}_{2}\right)$ level was strictly followed and as soon as the level reached to $l_{\text {, }}$ soda-lime was immediately replaced.

All patients were oxygenized for 2 minutes with a flow rate of $4 \mathrm{~L} /$ minutes before induction. Fentanyl $(1 \mathrm{mcg} /$ $\mathrm{kg}$ ), thiopental $(6 \mathrm{mg} / \mathrm{kg}$ ) and rocuronium $(0.6 \mathrm{mg} /$ $\mathrm{kg}$ ) were given by intravenous route for induction. After administration of thiopental, patients had been ventilated manually with $100 \% \mathrm{O}_{2}$ until endotracheal intubation was performed. 
Ventilation in volume control mode was provided by Dräger Primus ${ }^{\circledR}$ (Dräger Medizintechnic, Lübeck, Germany) anaesthesia system with a tidal volume of $7 \mathrm{mg} / \mathrm{kg}$, respiration frequency of 12 breaths/minutes and positive end-expiratory pressure of $5 \mathrm{~cm} \mathrm{H}_{2} \mathrm{O}$ thereafter.

Anaesthesia maintenance was performed by inhalation of low flow fresh gas mixtures including sevoflurane, nitrous oxide and $\mathrm{O}_{2}$. Content of gas mixture was set in pre-defined ratios regarding to the flow rate and taking this fact into account, entire population was gathered in three distinct groups.

In groups $A, B$ and $C, 40 \% \mathrm{O}_{2}, 60 \%$ nitrous oxide and $2 \%$ sevoflurane mixture was administered with a flow rate of $4 \mathrm{~L} /$ minutes for 10 minutes. Then, flow rate of fresh gas mixture was reduced to $2 \mathrm{~L}$ /minutes and $1 \mathrm{~L}$ /minutes in group $A$ and $B$, respectively. Sevoflurane concentration was kept between 1-2\% during the rest of anaesthesia for these groups. Although flow rate of $2 \mathrm{~L} /$ minutes is accepted as upper limit of low flow anaesthesia, in our study design this group was named as moderate flow group. Group B, was defined as low flow group, instead. In group $C$, flow rate was reduced to $0.5 \mathrm{~L} /$ minutes after 10 minutes of initial high flow anaesthesia and unlike other groups, $60 \% \mathrm{O}_{2^{\prime}} 40 \%$ $\mathrm{N}_{2} \mathrm{O}, 1-2 \%$ sevoflurane mixture was used for maintenance. This group was defined as minimal flow group.

Inhalation anaesthesia was ceased 10 minutes before termination of the procedure and at the end of operation, patients were ventilated with $100 \% \mathrm{O}_{2}$ at a flow rate of 6 $\mathrm{L} /$ minutes. When recovery of spontaneous breathing was observed, atropin $(0.01 \mathrm{mg} / \mathrm{kg})$ and neostigmin $(0.02 \mathrm{mg} /$ $\mathrm{kg}$ ) were administered for decurarization.

\section{Data Collection}

Demographic charactheristics including age, gender, body mass index, ASA score, surgical positions, and procedure times were noted for the study population. Blood pressure, oxygen saturation and heart rates of the patients were continuously monitorized and preprocedural, $30^{\text {th }}$ minute and postprocedural values were recorded. Following intubation, via gas samples collected from $Y$ connection, inspirated and expirated $\mathrm{O}_{2}$, volatile agent concentrations; on vaporizer, percentage of administered inhalation anaesthesia and end-tidal $\mathrm{CO}_{2}\left(\mathrm{ETCO}_{2}\right)$; and on ventilator, age adjusted minimum alveolar concentration (MAC) values were monitorized and regularly recorded. Blood samples were drawn for arterial blood gas analysis at the $30^{\text {th }}$ minute and before cessation of anesthesia.

Postoperative recovery process was observed and relevant data were collected by a second physician. Time to spontaneous breathing, time to extubation, time to eye opening, time to verbal response and time to reach a Modified Aldrete score of 9 or 10 were accepted as major determinants of recovery.

\section{Statistical analysis}

Statistical analyses were conducted using SPSS (version 17.0, SPSS Inc., Chicago, IL, USA). Data were expressed as mean \pm standard deviation for continuous variables and percentage for categorical variables. Normal distribution of the data was tested by the Shapiro-Wilk test. Student's t-test was used for comparing the means of the numeric variables that showed normal distribution, while the MannWhitney $U$ test was used for non-normally distributed samples. Associations of the categorical variables between groups were tested using chi-square test. For comparison of more than 2 groups, equality of the mean values was tested by One-Way ANOVA test. Statistical significance was defined as a $p$ value $<0.05$ for all comparisons.

\section{RESULTS}

Sixty-two patients were assembled in three groups according to the flow rate of gas mixture. Demographic charactheristics including age, gender, body mass index, ASA score, and procedure related factors like surgical positon and operation time were similar among groups (Table 1). Moreover, preoperative hemodynamic parameters were comparable (Table 2).

Similarity of vital monitorization parameters of study grups persisted at $30^{\text {th }}$ minute of operation. While $\mathrm{ETCO}_{2}$ values were not different, inspiratory sevoflurane concentration and MAC of sevoflurane were significantly higher in group A. As expected partial oxygen pressure and oxygen saturation were higher in minimal flow group due to increased ratio of oxygen in gas mixture. In blood gas analysis apart from oxygenation parameters, all but lactate levels were similar. Lactate levels were higher in low flow and minimal flow groups (Table 3).

Hemodynamic and respiratory monitorization data were recorded again just before cessation of inhalation anaesthesia and blood gas parameters were re-assessed as well. These data were displayed in Table 4. 
Table 1: Demographic charactheristics of study groups

\begin{tabular}{|c|c|c|c|c|}
\hline & Group A $(n=21)$ & Group B $(n=20)$ & Group C $(n=21)$ & p value \\
\hline Gender (male), n (\%) & $15(71.4)$ & $12(60)$ & $17(80.9)$ & 0.335 \\
\hline Age, years & $51.0 \pm 12.7$ & $49.4 \pm 12.6$ & $55.9 \pm 15.8$ & 0.296 \\
\hline BMI, $\mathbf{k g} / \mathrm{m}^{2}$ & $27.1 \pm 5.3$ & $29.5 \pm 6.0$ & $26.3 \pm 3.8$ & 0.133 \\
\hline \multicolumn{5}{|l|}{ ASA score, n (\%) } \\
\hline 1 & $6(28.5)$ & $7(35)$ & $9(42.8)$ & 0.619 \\
\hline 2 & $15(71.4)$ & $13(65)$ & $12(57.1)$ & \\
\hline \multicolumn{5}{|l|}{ Surgical position, $\mathrm{n}(\%)$} \\
\hline Lateral & $4(19)$ & $3(15)$ & $3(14)$ & 0.851 \\
\hline Supine & $9(42)$ & $9(45)$ & $8(38)$ & \\
\hline Lithotomy & $8(38)$ & $8(40)$ & $10(47)$ & \\
\hline Operation time, minutes & $145.9 \pm 65.1$ & $122.1 \pm 55.0$ & $100.4 \pm 46.6$ & 0,102 \\
\hline
\end{tabular}

Table 2: Preoperative hemodynamic data

\begin{tabular}{lllll}
\hline & Group A (n=21) & Group B (n=20) & Group C (n=21) & p value \\
\hline Systolic BP, $\mathbf{~ m m H g}$ & $146.6 \pm 20.7$ & $153.4 \pm 19.3$ & $149.5 \pm 20.6$ & 0.569 \\
Diastolic BP, $\mathbf{~ m m H g}$ & $87.9 \pm 15.6$ & $94.2 \pm 17.7$ & $88.3 \pm 11.7$ & 0.336 \\
Mean BP, $\mathbf{~ m m H g}$ & $112.9 \pm 18.4$ & $116.1 \pm 17.4$ & $115.4 \pm 16.7$ & 0.825 \\
Pulse rate, bpm & $78.5 \pm 12.3$ & $81.3 \pm 15.3$ & $76.0 \pm 11.8$ & 0.142 \\
$\mathbf{S a O}_{\mathbf{2}}$ \% & $98.2 \pm 1.9$ & $97.7 \pm 1.4$ & $97.9 \pm 1.2$ & 0.253 \\
\hline BP: Blood pressure, $\mathrm{SaO}_{2}$ : Oxygen saturation & & & \\
\hline
\end{tabular}

Table 3: Hemodynamic parameters, respiratory monitorization and blood gas analysis data obtained at $30^{\text {th }}$ minute of operation

\begin{tabular}{|c|c|c|c|c|}
\hline & Group A (n=21) & Group B $(n=20)$ & Group C $(n=21)$ & $\mathrm{p}$ value \\
\hline Mean BP, mmHg & $89.1 \pm 15.9$ & $92.6 \pm 13.7$ & $94.5 \pm 20.1$ & 0.575 \\
\hline Pulse rate, bpm & $72.2 \pm 15.7$ & $78.7 \pm 17.3$ & $69.5 \pm 11.2$ & 0.140 \\
\hline $\mathrm{ETCO}_{2^{\prime}} \mathrm{mmHg}$ & $31.3 \pm 2.9$ & $31.9 \pm 2.5$ & $31.7 \pm 3.0$ & 0.853 \\
\hline $\mathrm{InsO}_{2^{\prime}}, \mathrm{mmHg}$ & $39.6 \pm 1.3$ & $39.1 \pm 1.6$ & $52.7 \pm 4.3$ & $<0.001^{*}$ \\
\hline Ins sevo, \% & $1.7 \pm 0.6$ & $1.3 \pm 0.3$ & $1.3 \pm 0.3$ & $0.043^{*}$ \\
\hline MAC & $1.3 \pm 0.3$ & $1.1 \pm 0.1$ & $0.9 \pm 0.2$ & $<0.001^{*}$ \\
\hline pH & $7.39 \pm 0.06$ & $7.39 \pm 0.04$ & $7.40 \pm 0.03$ & 0.714 \\
\hline $\mathrm{pO}_{2}, \mathrm{mmHg}$ & $168.6 \pm 43.9$ & $165.4 \pm 39.9$ & $245.5 \pm 51.5$ & $<0.001^{*}$ \\
\hline $\mathrm{pCO}_{2}, \mathrm{mmHg}$ & $38.5 \pm 3.0$ & $37.4 \pm 3.7$ & $38.9 \pm 4.2$ & 0.434 \\
\hline $\mathrm{SaO}_{2}, \%$ & $168.6 \pm 43.9$ & $165.4 \pm 39.9$ & $245.5 \pm 51.5$ & $<0,001^{*}$ \\
\hline Lactate, mmoL/L & $1.04 \pm 0.56$ & $1.29 \pm 0.49$ & $1.33 \pm 0.46$ & $0.038^{*}$ \\
\hline Base excess & $-2.06 \pm 3.48$ & $-2.64 \pm 1.96$ & $-1.03 \pm 2.18$ & 0.186 \\
\hline $\mathrm{COHb}, \%$ & $1.33 \pm 0.46$ & $1.27 \pm 0.32$ & $1.39 \pm 0.52$ & 0.967 \\
\hline
\end{tabular}

BP: Blood pressure, $\mathrm{ETCO}_{2}$ : end-tidal carbon dioxide pressure, Ins $\mathrm{O}_{2}$ : Inspiratory oxygen pressure, Ins sevo: Inspiratory sevoflurane concentration, MAC: Minimum alveolar concentration, $\mathrm{pH}$ : Power of hydrogen, $\mathrm{pO}_{2}$ : Partial pressure of oxygen, $\mathrm{pCO}_{2}$ : Partial pressure of carbon dioxide, $\mathrm{SaO}_{2}$ : Oxygen saturation, $\mathrm{COHb}$ : Carboxyhemoglobin 


\begin{tabular}{|c|c|c|c|c|}
\hline & Group A $(n=21)$ & Group B $(n=20)$ & Group C $(n=21)$ & p value \\
\hline Mean BP, mmHg & $89.8 \pm 19.6$ & $95.7 \pm 20.3$ & $95.4 \pm 16.3$ & 0.529 \\
\hline Pulse rate, bpm & $71.5 \pm 18.4$ & $72.5 \pm 12.9$ & $68.8 \pm 12.8$ & 0.657 \\
\hline $\mathrm{ETCO}_{2}, \mathrm{mmHg}$ & $31.9 \pm 3.2$ & $32.6 \pm 3.4$ & $31.9 \pm 3.1$ & 0.275 \\
\hline $\mathrm{InsO}_{2}, \mathrm{mmHg}$ & $38.4 \pm 1.5^{*}$ & $35.0 \pm 2.0^{*}$ & $52.1 \pm 3.6$ & $<0.001^{*}$ \\
\hline Ins sevo, \% & $1.6 \pm 0.5$ & $1.3 \pm 0.4$ & $1.3 \pm 0.3$ & 0.180 \\
\hline MAC & $1.3 \pm 0.3$ & $1.2 \pm 0.2$ & $1.0 \pm 0.2$ & $0.001^{*}$ \\
\hline pH & $7.38 \pm 0.07$ & $7.38 \pm 0.05$ & $7.39 \pm 0.03$ & 0.599 \\
\hline $\mathrm{pO}_{2}, \mathrm{mmHg}$ & $165.6 \pm 41.8$ & $152.7 \pm 64.3$ & $227.9 \pm 46.7$ & $<0.001^{*}$ \\
\hline $\mathrm{pCO}_{2}, \mathrm{mmHg}$ & $37.3 \pm 4.3$ & $38.1 \pm 3.9$ & $39.3 \pm 4.9$ & 0.328 \\
\hline $\mathrm{SaO}_{2}, \%$ & $98.08 \pm 1.42$ & $98.06 \pm 2.11$ & $98.81 \pm 1.08$ & $0.028^{*}$ \\
\hline Lactate, mmoL/L & $1.08 \pm 0.48$ & $1.27 \pm 0.58$ & $1.22 \pm 0.52$ & 0.623 \\
\hline Base excess & $-3.12 \pm 3.65$ & $-3.82 \pm 2.21$ & $-1.65 \pm 2.74$ & 0.087 \\
\hline COHb, \% & $1.36 \pm 0.50$ & $1.32 \pm 0.33$ & $1.33 \pm 0.4$ & 0.767 \\
\hline
\end{tabular}

BP: Blood pressure, $\mathrm{ETCO}_{2}$ : End-tidal carbon dioxide pressure, InsO $\mathrm{I}_{2}$ Inspiratory oxygen pressure, Ins sevo: Inspiratory sevoflurane concentration, MAC sevo: Minimum

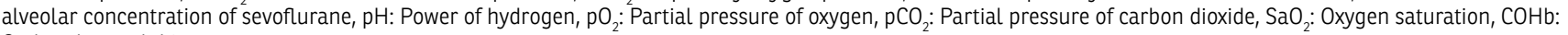
Carboxyhemoglobin

\begin{tabular}{|c|c|c|c|c|}
\hline & Group A $(n=21)$ & Group B $(n=20)$ & Group C $(n=21)$ & $\mathrm{p}$ value \\
\hline Time to spontaneous breathing, minutes & $0.8 \pm 1.2$ & $1.2 \pm 1.7$ & $1.4 \pm 1.5$ & 0.210 \\
\hline Time to eye opening, minutes & $6.8 \pm 4.5$ & $7.3 \pm 3.6$ & $8.2 \pm 3.5$ & 0.500 \\
\hline Time to verbal response, minutes & $9 \pm 5.5$ & $8.8 \pm 3.9$ & $10 \pm 3.8$ & 0.518 \\
\hline
\end{tabular}

Values regarding oxygenation were still higher in group $\mathrm{C}$ at the end of operation. Not inspiratory concentration but MAC of sevoflurane was lower in this group. Difference at lactate levels favoring group $A$ at $30^{\text {th }}$ minute was eventually diminished and lost statistical significance.

Time to spontaneous breathing, time to extubation, time to eye opening, time to verbal response and time to reach a Modified Aldrete score of 9 or 10 were determined as indicators of recovery. And there were no statistically significant differences among groups regarding these data (Table 5).

\section{DISCUSSION}

Main goals of anaesthesia practice are appropriate induction phase without causing hemodynamic deterioration, maintenance of perioperative stability, rapid recovery free of side effects and early mobilization (9).
Low flow anaesthesia had been authenticated for meeting these properties in addition to various advantages like reduced gas consumption which leads to reduced costs, less personnel exposure and less pollution, preserved heat and humidity of respiratory system and improved flow dynamics $(2,4)$.

In conventional low flow anaesthesia, inhalation agents such as sevoflurane, isoflurane and desflurane are widely used $(10,11)$. Sevoflurane is one of the safest volatile anesthetic agents with the desirable properties of rapid uptake and elimination due to its low blood/gas solubility which makes it favorable for this technique $(12,13)$.

Increased health expenditures and air pollution are two major entities that accentuated the usage of low flow technique. Approximately $80 \%$ of volatile anaesthetics are eliminated without utilization in high flow anaesthesia. Not only the ozone layer but also the operation room staff is directly influenced from this adversity (14). 
Aside from these facts, preserving the heat and moisture of gas mixtures is another advantage of low flow technique. Modulating the gas climate via this method improves the functionality of ciliary epithelium and mucus clearance. Keeping the heat is also crucial for avoiding postoperative hypothermia (15).

Another keypoint of proper anaesthetic management in low flow systems is maintenance of humidity in absorbent agent to keep CO production in clinically insignificant levels (15). In response to superiority of wet absorbents over dry agents on anaesthetic gas degredation properties which favor their utilization in low flow systems, these systems help keeping humidity by increasing generation of additional water during re-breathing phase (16). Fang et al. encouraged utilization of fresh gas flow below 2-3 L/minutes to prevent the absorbent from accidentally drying process (17). A randomised investigation on 1258 subjects supported this finding and reducing the flow rate down to $0.5 \mathrm{~L} /$ minutes after induction resulted in $\mathrm{COHb}$ levels of $1.22 \pm 0.98 \%$ at $30^{\text {th }}$ minute and this endpoint had not been altered by the time passed since absorbent had been replaced even if the replacement had been constantly executed once a week (18). Moreover, in a different investigation usage of extremely low gas flow rates and once a week replacement of absorbent did not yield a significant or critical rise at $\mathrm{COHb}$ levels (19). We preferred to change soda lime when $\mathrm{CO}_{2}$ level at inspiratory gas mixture $\left(\mathrm{FiCO}_{2}\right)$ reached $\mathrm{l}$ with the advantage of $\mathrm{CO}_{2}$ monitoring ability of devices. $\mathrm{COHb}$ levels were similar among groups and none of them was above the limits.

Risk of hypoxia should also be concerned in low flow anaesthesia. According to Brody's equation oxygen consumption of an unanaesthetized healthy individual weighing $70 \mathrm{~kg}$ is $250 \mathrm{~mL} /$ minutes (20). Spiess investigated the effect of depth of anaesthesia and certain agents on oxygen consumption in low flow anaesthesia and declared that during minimal flow anaesthesia oxygen consumption was reduced to $165 \mathrm{~mL} /$ minutes at $1 \mathrm{MAC}$ (21). As gas flow rate decreases, gradient between oxygen content and inspirated oxygen concentration gradually increases. To avoid hypoxemia precisely and to maintain a constant oxygen supply $\mathrm{FiO}_{2}$ should be kept over $30 \%$ at least (22). Grote denoted the necessity of increasing the $\mathrm{O}_{2}$ flow to $0.6 \mathrm{~L} /$ minutes when total gas flow was $1 \mathrm{l} /$ minutes particularly for the operations lasting more than an hour.
Besides, they did not recommend routine monitorization of oxygenation in low flow anaesthesia if $\mathrm{FiO}_{2}$ levels had been set in pre-defined rates (23). In 1998, Frink and Kharash also mentioned about the risk of hypoxia when low flow anesthesia with sevoflurane mixture was administered (24). In our study design, to consider this issue, in moderate and low flow groups $\mathrm{FiO}_{2}$ was kept at $40 \%$ and in minimal flow group it was $60 \%$. We preferred to monitorize $\mathrm{FiO}_{2}$ levels and other oxygenation parameters and observed that in minimal flow group these were significantly higher than others. Regarding these findings, if gas flow rate will be reduced to $1 \mathrm{~L} /$ minutes, we recommend setting the initial gas fractions as $50 \% \mathrm{O}_{2}$ and $50 \% \mathrm{~N}_{2} \mathrm{O}$ for operations over 1 hour, especially when $\mathrm{FiO}_{2}$ monitorization is not available.

Depth of anaesthesia is another key paramater to compare during general anaesthesia with different flow rates of fresh gas mixtures. Depth is clinically assessed by sympathetic and somatic response to painful stimuli. Indicators of sympathetic stimulation are gradual increase in systolic arterial pressure and heart rate, diaphoresis and alterations of pupil diameter. Sustained utilization of neuromuscular blocking agents supress somatic response and narcotic analgesics alter pupillary response, thus precludes accurate evaluation. Particularly in low flow anaesthesia, regarding the fact that inspired and expired gases are constantly merged, inspired gas concentration is not precisely concordant with vaporizer settings. As a result, modulating anaesthesia depth is troublesome unless continuous gas monitorization is available (25-27). We evaluated the depth of anaesthesia by following heart rate and arterial blood pressure along with inspiratory sevoflurane monitorization. No statistically significant difference was reached among study groups according to hemodynamic data. Although inspiratory sevoflurane concentration was higher in moderate flow group at $30^{\text {th }}$ minute, this gap was reduced and lost statistical significance at the end of anaesthesia. Several other studies investigating the effect of low flow desflurane anaesthesia on perioperative blood pressure and heart rate measurements in pediatric and adult population exist in the literature. They did not report a marked diversity either, even when low flow technique was used $(28,29)$.

Tokgoz et al. stated in their trial comparing high flow and low flow anaesthesia that lactate values at blood gas analysis were apparently higher in low flow group (30). In 
our study, similar findings were attained. Although there was a statistical significance favoring moderate flow at the early phase of operation, before cessation of anaesthesia lactate levels were only tended to be lower in this group. Fortunately, all these values were in normal ranges and we reached a decision that this distinction had not indicated an evident deprivation in tissue oxygenation especially when similarites between oxygen transportation parameters among groups were considered.

For terminating anaesthesia, infusion of volatile anaesthetic agents to fresh gas mixture might be halted 15-30 minutes prior to cessation of surgical intervention by turning the vaporizer off while preserving the total fresh gas volume. This situation is based on extent of time constant. Thereby, the slower gas flows, the slower inhalating agent concentration reduces. After these arrangements at the very end of the procedure, adjustable pressure limiting valve is opened and $\mathrm{O}_{2}$ flow rate is enhanced to 4-6 L/ minutes to eliminate anaesthetic gases and get prepared for recovery (15).

Recovery in inhalation anaesthesia is associated with multiple factors like liposolubility, concentration, utilization period of the agent and individual alveolar ventilation rate. Early recovery occurs approximately in 15 minutes after inhalation anaesthesia of 2 hours duration (31,32). It is crucial to denote that inhalating agents constitute a certain part of balanced general anaesthesia, thus several other entities play role in recovery process $(32,33)$. Hence for research purposes, merely following a fixed inhalation anaesthesia protocol as well as standardizing opioid and neuromuscular blocking agent amounts can provide a self-directed recovery to some extent.

Lastly, one of the main goals of our investigation was to determine whether gradual decrease in gas flow rate had deleterious effects on recovery status. Time consumed for various recovery indicators like time to extubation, time to eye opening and time to orientaton -namely modified Aldrete score of 9 or 10 - were used for assessment. Recovery times in all study groups were comparable with previous similar studies performed with conventional flow rates of gas mixtures ( $>3 \mathrm{~L} /$ minutes) involving sevoflurane $(26,34,35)$.

Limited numbers of studies utilizing low flow gas mixtures and considering recovery as an endpoint exist in the literature. Elmacıoğlu et al. stated that low flow anaesthesia utilizing desflurane might be safely adminstered to patients with ASA score I or II. They also emphasized that low flow anaesthesia had no adverse effect on hemodynamic stability and recovery phase irrespective of the flow rates (0.5, 1 and $2 \mathrm{~L} /$ minutes) and could be an alternative to conventional inhalation anaesthesia (29). Okada et al. reported the safety of $3 \%$ sevoflurane, $50 \%$ nitrous oxide and $50 \% \mathrm{O}_{2}$ mixture administered at a flow rate of $600 \mathrm{~mL} /$ minutes without the risk of hypoxia and retarded recovery (36). Our research verified the fact that reducing the flow rate even to $0.5 \mathrm{~L} /$ minutes did not elicit a significantly prolonged recovery phase for low flow anaesthesia utilizing sevoflurane.

\section{Study Limitations}

Relatively small study population should be considered as main limitation of the study. Randomizing the individuals from a specific surgical procedure, brief randomization interval and strict exclusion criteria led to this situation. But it was mandatory to minimize the variables that may alter the results about such a multifactorial process. Apart from that anaesthesia depth was evaluated with indirect parameters instead of Bispectral Index monitorization due to unavailability of the device. Finally, oxygen concentration of the gas mixture could be set to a value lower than $\% 60$ for minimal flow group. Concerns about the risk of hypoxia in this group led to iatrogenic hyperoxia during anaesthesia.

\section{CONCLUSION}

Widespread utilization of low flow anaesthesia is a cornerstone for the evolution of inhalation anaesthesia regarding the cost reduction efforts of public health policies and conservation of the personnels' health and air purity. From this point of view, it is reasonable to suggest that less is better. Usage of semi-closed breathing systems, proper selection of cuffed endotracheal tubes and paying special attention on leakages may substantially decrease gas exposure during low flow anaesthesia. Here we report the safety -by means of avoiding hypoxia, acidosis, hemodynamic disturbance and retarded recovery phaseof administering gas mixtures with sevoflurane even at very low flow rates which meet the needs of modern inhalation anaesthesia. Obviously, verification with larger study populations is required to express more precise statements. 


\section{Etik}

Etik Kurul Onayı: Haseki EAH etik kurulu, No:56

Hasta Onayı: Alındı.

Çıkar Çatışması: Yok

Finansal Destek: Yok

\section{REFERENCES}

1. Eger El II. Uptake and distribution. In: Miller RD (Ed.) Anesthesia. 6th ed. Philadelphia: Elsevier Churchill Livingstone; 2005:131-53.

2. Baum JA, Aitkenhead AR. Low-flow anaesthesia. Anaesthesia 1995;50:37-44.

3. Nunn G. Low-flow anesthesia. Contin Educ Anaesth Crit Care Pain 2008;8:1-4.

4. Baum JA. Low-flow anesthesia: Theory, practice, technical preconditions, advantages, and foreign gas accumulation. J Anesth 1999;13:166-74.

5. Aldrete JA, Cubillos P, Sherrill D. Humidity and temperature changes during low flow and closed system anaesthesia. Acta Anaesthesiol Scand 1981;25:312-4.

6. Kleemann PP. Humidity of anaesthetic gases with respect to low flow anaesthesia. Anaesth Intensive Care 1994;22:396-408.

7. Suttner S, Boldt J. Low-flow anaesthesia. Does it have potential pharmacoeconomic consequences? Pharmacoeconomics 2000;17:585-90.

8. Tempia A, Olivei MC, Calza E, Lambert H, Scotti L, Orlando E, et al. The anesthetic conserving device compared with conventional circle system used under different flow conditions for inhaled anesthesia. Anesth Analg. 2003;96:1056-61.

9. Ceylan A, Kırdemir P, Kabalak A, Aksu C, Baydar M, Gögüs N. Comparison of arterial carboxyhemoglobin, hemodynamic and recovery characteristics of low flow desflurane and sevoflurane anesthesia. Gulhane Medical Journal 2004;46:294.

10. Kharasch, ED, Thummel KE. Identification of cytochrome P450 2El as the predominant enzyme catalyzing human liver microsomal defluorination of sevoflurane. Anaesthesiology 1993;79:795-807.

11. Eger, El 2nd. New drugs in anesthesia. Int Anesthesiol Clin 1995;33:6180.

12. Bito $H$, Ikeda $K$. Renal and hepatic function in surgical patients after low-flow sevoflurane or isoflurane anesthesia. Anesth Analg 1996;82:173-6.

13. Philip BK, Kallar SK, Bogetz MS, Scheller MS, Wetchler BV. A multicenter comparison of maintenance and recovery with sevoflurane or isoflurane for adult ambulatory anesthesia. Anesth Analg 1996;83:314-9.

14. Baum JA. What are the ecological benefits of low flow anaesthesia? In: Baum JA (Ed). Low-Flow Anaesthesia with Drager Machines, 2nd Ed. Dragerwerk AG, Lübeck, 1993:52.
15. Baum JA. Low Flow Anaesthesia: The Theory and Practice of Low Flow, Minimal Flow and Closed System Anaesthesia, 4th ed. Oxford: Butterworth-Heinemann; 2001.

16. Eger El II, lonescu P, Gong D. Circuit absorption of halothane, isofluarane and sevofluarane. Anesth Analg 1998;86:1070-4.

17. Fang ZX, Eger El II, Laster MJ, Chortkoff BS, Kandel L, Ionescu P. Carbon monoxide production from degradation of desflurane, enflurane, isoflurane, halotane, and sevoflurane by sodalaym and baralyme. Anesth Analg 1995;80:1187-93.

18. Baum J, Sachs G, vd Driesch C, Stanke HG. Carbon monoxide generation in carbon dioxide absorbents. Anaesth Analg 1995;81:144-6.

19. Morita S. Inspired gas contamination buy non anesthetic gases during closed circuit anesthesia. Circular 1985;2:24-5.

20. Brody S. Bioenergetics and Growth. New York: Reinhold Publishing Corp; 1945.

21. Spiess $W$. Oxygen consumption and intake of nitrous oxide and volatile anesthetics. In: Lavin P, H von Aken, U Schneider, Alternative methoden der anaesthesia Theime Studgart: INA-Schriftenreihe Bd.; 1985:8-18.

22. Hendrickx JFA, Cooman DS, Vandeput DM, et al. Air-oxygen mixtures in circle systems. Journal of Clinical Anesthesia 2001;13:461-4.

23. Grote B. Principles of the closed system inhalation anesthesia. In: Hossli G, Frey P, Kreienbühl G(Ed.) ZAK Zurich, Band II. Zurich: Springer Vertag; 1983:137-42

24. Frink EJ, Kharash E. Sevoflurane in low flow anaesthesia. In: Low flow anaesthesia and the role of sevoflurane: A contemporary clinical perspective, Adis International Inc. 1998:25-40.

25. Göğüş $D$, Göksu $S$, Öner Ü, Altıntaș $F$. Administration of low flow anesthesia. Klinik Gelișim 1999;12:813-16.

26. Gowrhe-Mohan S, Chakrabartı MK, Lockwood GG. The estimation of inspired isoflurone concentration in a low flow system. Anaesthesia 1995;50:706-8.

27. Christina MB. Clinical comparison of sevoflurane and isoflurane when administered with nitrous oxide for surgical pocedures of intermediate duration. Can J Anaesth 1995;42:1991-5.

28. Yıldız TŞ, Baykara N, Bozkurt N, Oysu DA, Solak M, Toker K. Impact of clonidine on tremor in low-flow desflurane anesthesia, Türk Anest Rean Der Dergisi 2005;33:29-35.

29. Elmacıoğlu MA, Göksu S, Koçoğlu H, Oner U. Effect of flow rate on hemodynamic parameters and agent consumption in low-flow desflurane anesthesia: An open labels prospective study in 90 patients. Current Therapeutic Research 2005;66:4-12.

30. Tokgöz N, Ayhan B, Sarıcaoğlu F, Akıncı SB, Aypar U. Comparison of low and high flow desflurane anesthesia in pediatric population. Türk J Anaesth Reanim 2012;40:303-9.

31. Xie G, Jiang H. Clinical study of desflurane on low flow anesthesia compared with sevoflurane and enflurane. Chin Med 1997;110:707-10.

32. Aitkenhead AR, Smith G. Textbook of Anesthesia, 6th ed. London: Churchill Livingstone; 2013. 
33. Tarazi, EM, Philip BK. A Comparison of recovery after sevoflurane or desflurane in ambulatory anesthesia. J Clin Anesth 1998;10:272-7.

34. Nathanson MH, Fredman B, Smith I, Whie PF. Sevoflurane versus desflurane for outpatient anesthesia. A comparison of maintenance and recovery profiles. Anesth Analg 1995;81:1186-90.
35. Philip BK. Multicenter Comparison of Maintenance and Recovery with Sevoflurane or Isoflurane for Adult Ambulatory Anesthesia. Anesth Analg 1996;83:314-9.

36. Okada K, Asano N, Kimura O, Okada H, Nishio S, Wakusawa R. Low flow anesthesia using a fresh gas flow of $600 \mathrm{ml}$.min-1 for 5 hours. Masui 1997;46:1321-8. 